\title{
走査プローブ顕微鏡
}

\section{Scanning Probe Microscope}

Hiroyuki MASUDA*

Key Words : STM, AFM, Aqueous Environment, Atom, Nanoprocessing

1981年 IBM研究所で Binnig らにより発明された STM，またその後発明された絶縁物でも測定可能 なAFMは材料研究に新しい可能性を開いた。ここではこれらの顕微鏡の原理と応用例について述べる。

\section{1.はじめに}

今まで多くの科学者は原子を直接見る・動かす という夢を追ってきた。その夢をかなえたのが走 查トンネル顕微鏡 (STM : Scanning Tunneling Microscope）の出現である。STMは，1981年ス イスの IBM研究所で Binnig ら ${ }^{1)}$ にり発明され た。またSTMが導電性材料しか見えない欠点を 補うため, 絶縁物でも測定可能な原子間力顕微鏡 (AFM : Atomic Force Microscope) を Binnig らはスタンフォード大学と協力して開発した。こ れら両顕微鏡とも電圧をかけることにより非常に 小さな変形をおこす圧電体でXYZ方向に移動可 能なステージを構成し, 非常に小さなプローブを 走查してデータを取り込み, 画像化している。こ の原理に基づく顕微鏡は一般に走查プローブ顕微 鏡 (SPM : Scanning Probe Microscope) と呼 ばれ，現在では非常に多くの種類のものが考案さ れている。ここではこれらの顕微鏡の原理と応用 例について述べる。

* 金属材料技術研究所 筑波支所（二305 茨城県つくば市千現 12-1)

National Res. Inst. for Metals, Tukuba Labs. (2-1, Sengen 1-chome, Tsukuba-shi, Ibaraki 305)

\section{STM, AFMの原理}

\section{1 STMの原理}

STMは一般に図 1 に示すように, 鋭くとがっ た金属針を導電性の試料表面から $1 \mathrm{~nm}$ 以下まで 近づけた時に流れるトンネル電流を一定に保つ（= 探針と試料の距離を一定に保つ）ように制御して 試料表面を $\mathrm{X}-\mathrm{Y}$ 方向に走査する。その時各地点 の高さ方向の圧電体の変位 $Z$ を画像化することに より表面形状を表すすのである。トンネル電流が 探針と試料の距離にほぼ指数関数的に比例するの で（例えばトンネル電流が 10 倍变化しても探針 と試料の距離は $0.1 \mathrm{~nm}$ 程度しか変化しない), 高 さ方向の分解能は $0.01 \mathrm{~nm}$ 以下と非常に高いのが 特徴である。

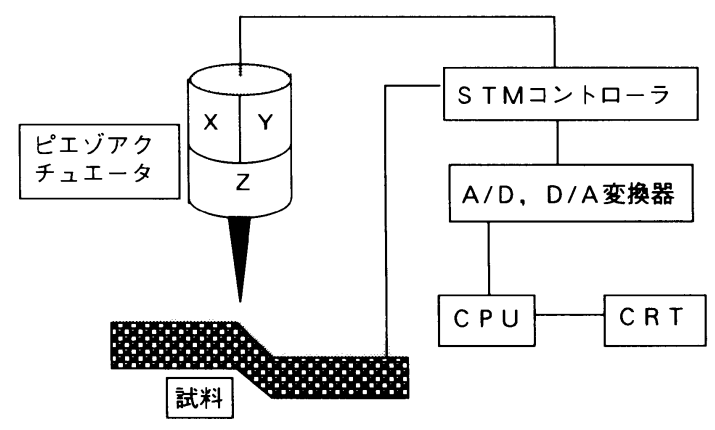

図 1 STMの制御 


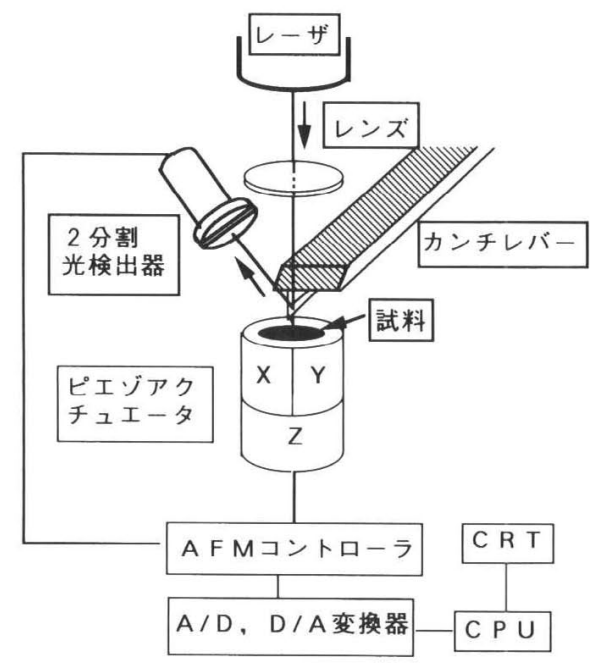

図 2 AFMの制御方法

\section{2 AFMの原理}

一般に使われている AFMは絶縁性の針を付け た非常に小さなバネを圧電素子上に固定し，その たわみ量が一定になるように制御して試料表面を $\mathrm{X}-\mathrm{Y}$ 方向に走查するあのである。バネのたわみ 量の制御は図 2 に示すようにバネの背面にレーザ 光をあてその反射角がバネの変位によって変化す ることを利用して，反射した光を 2 分割フォトダ イオードで検出し，バネの変位が一定になるよう 制御し，Z方向の変位を読みとるものである。 AFMはバネのたわみ量が一定になるよう制御す るため, 絶縁性の材料でも形状をとることが可能 である。

\section{STM, AFMの諸機能}

\section{1 形状測定}

STM, AFMの第 1 の機能として形状測定が挙 げられる。表面形状を観察する装置として透過型 電子顕微鏡 $(\mathrm{TEM})$ や走查型電子顕微鏡 $(\mathrm{SEM})$ が よく使われるが，これらの顕微鏡に比較して高さ 方向の分解能が著しく高い。図 3 はその一例で, $\mathrm{Fe}$ を $300^{\circ} \mathrm{C} ， 5 \mathrm{~Pa}$ の条件で 10 秒酸化させたもの を AFM観察したもので, 直径50〜100nm, 高さ 10 30nmの酸化物粒子がところよ゙ころに発生し ているのがわかるが, SEMでは同倍率での観察 において酸化物を見ることができなかった。この

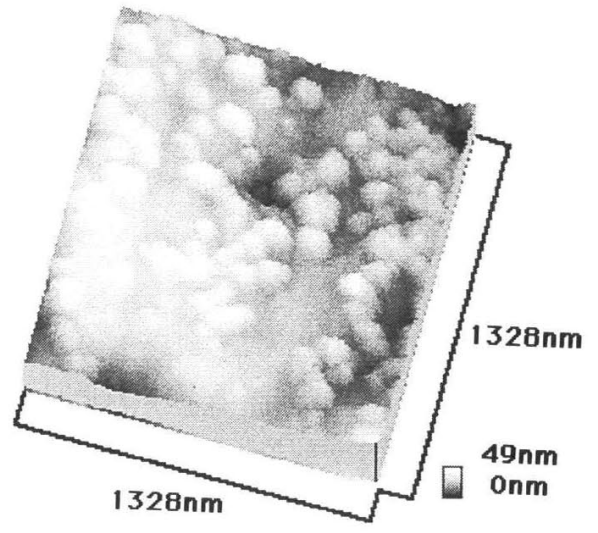

図 3 純鉄上に形成された酸化物粒子の AFM像

ように STMやAFMは非常に微少な凹凸を測定 するには非常に適した機器である。また逆に大 きな凹凸を測定するにはあまり適していない。 STMを用いた形状測定の研究として初期には $\mathrm{Si}$ や GaAsなどの半導体の表面の構造解析が盛ん に行われた ${ }^{2) \sim 7) 。 そ の な か て ゙ あ ~} \mathrm{Si} の(111)$ 面の $7 \times 7$ 構造は, 現在では超高真空中の STM観察 の標準物質となっている。金属原子の観察は STM研究の当初は理論的にも実験的にも不可能 と思われていたが, 先端の鋭い針で除振やフィー ドバック回路を改善し安定性のあるSTMを用い ることにより金属 $(\mathrm{Au})$ の原子観察が可能である ことを Kukら ${ }^{8)}$ は示した。その後 $\mathrm{Al}, \mathrm{Cu}, \mathrm{Ni}$, $\mathrm{Ag}$ など ${ }^{9) ~ 11)}$ 多くの金属の原子像が現在では超高 真空中で観察されている。また水溶液中であ

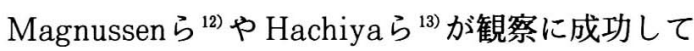
いる。

AFMは開発当初分解能が STMより 1 桁以上悪 く原子像をとることが困難であったが，装置の 改良により原子像が観察されるようになった。 Albrechtら ${ }^{14)}$ は絶縁材料(BN)の原子像の観察に 初めて成功した。またHansma グループ ${ }^{15)}{ }^{16)}$ は 水溶液中で銅原子の観察やその溶解過程の観察な ぞに成功している。

STM，AFMともに原子像の観察には除振など 環境を安定したものに整備する必要があるが, .数 $\mathrm{nm}$ から数 $\mu \mathrm{m}$ の範囲の表面形状を観察すること は比較的容易である。そこで半導体, 金属, 有機。 バイオ，高分子など多方面の研究がこの範囲で行 
われている。水溶液中の反応過程の研究について は, 著者ら ${ }^{17) \sim 19)}$ はSTMを用いて $1 \% \mathrm{NaCl}$ 及び $0.1 \% \mathrm{HNO}_{3}$ 水溶液中で各種鉄鋼材料の腐食過程 及び $0.1 \mathrm{M} \mathrm{CuSO}_{4}+\mathrm{H}_{2} \mathrm{SO}_{4}$ 水溶液中における銅 の金電極上への電析過程, 溶解過程のその場観察 （図4）や画像差分を用いた反応の定量解析に成 功している。AFMを用いたあのとしてはHansma グループ20)によって $0.015 \mathrm{~N}$ 水酸化ナトリウム水 溶液中に打ける $\mathrm{CaCO}_{3}$ 表面のエッチピットの成 長過程のその場観察が報告されている。

\section{2 加工}

STM，AFMは表面形状の観察だけでなく加工 という機能を持つ。しかしある程度精度良く加工， を行うためには，装置の改良，プログラムの開発 などが要求されるのであまり多くは行われていな い。加工で最も有名なものは Eiger グループ21), 22) が行った原子 1 個 1 個を動かして文字を描くとい
うあのである。彼らは原子の動きをとめるために 基盤を $4 \mathrm{~K}$ という極低温まで冷却して実験を行っ た。まず探針を比較的遠ざけて走査し STM像を とり, 基盤上に点在する移動を行う Xe原子の位 置を確認後，探針を移動させる原子の位置にもっ ていき, 探針と Xe原子の引力が Xe原子と $\mathrm{Ni}$ 基 盤の引力より大きくなるよう探針を近づけ Xe原 子を移動させ IBMという文字を描いた。また同 様な于段で CO分子を用いて CO と言う文字やモ ラキュラーマンと称す人形の絵を描いたりした。 一方, 細木ら ${ }^{23)}$ は $\mathrm{MoS}_{2}$ のへき開面上の硫黄原子 1 個 1 個を除去して文字を描くことに成功した。 これは除去したい原子の上に探針をもっていき高 い電圧をかけ原子をとばすもので, 電界蒸発加工 の一種と考えられる。原子 1 個 1 個ではないが同 様な手法で Albrechtら ${ }^{24)}$ はグラファイトに，ま た岩梘ら ${ }^{25)}$ は Si (111)面上に文字を描くことに成

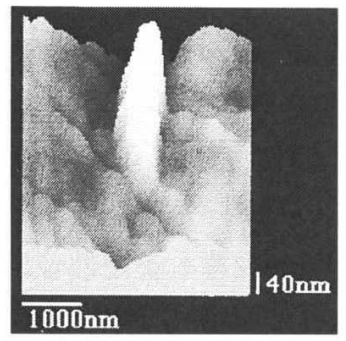

開始時

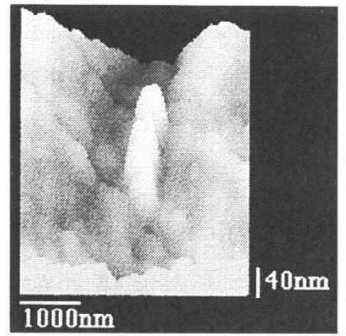

6 分後

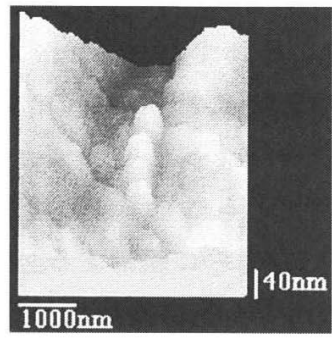

12 分後

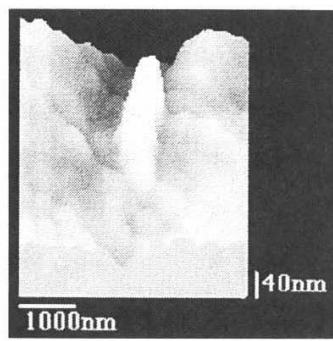

2 分後

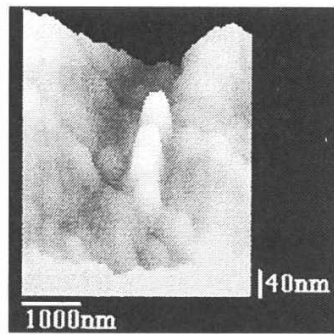

8 分後

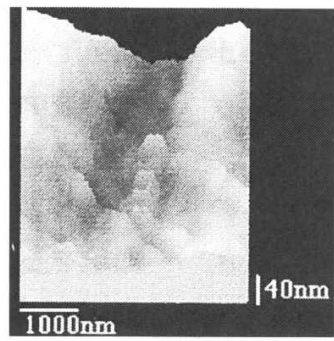

13 分後

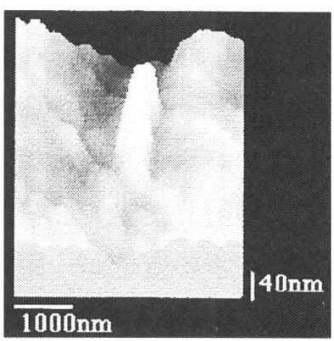

4 分㖟

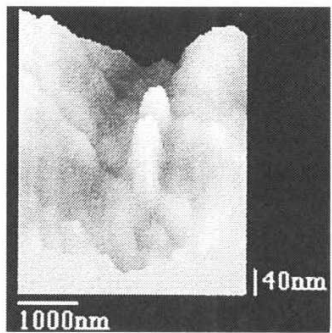

10 分後

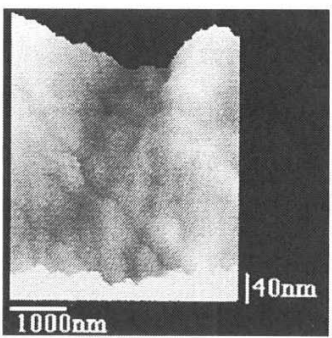

14 分後

図 4 金電極上に電解析出させた銅粒子のアノード溶解過程のその場観察 


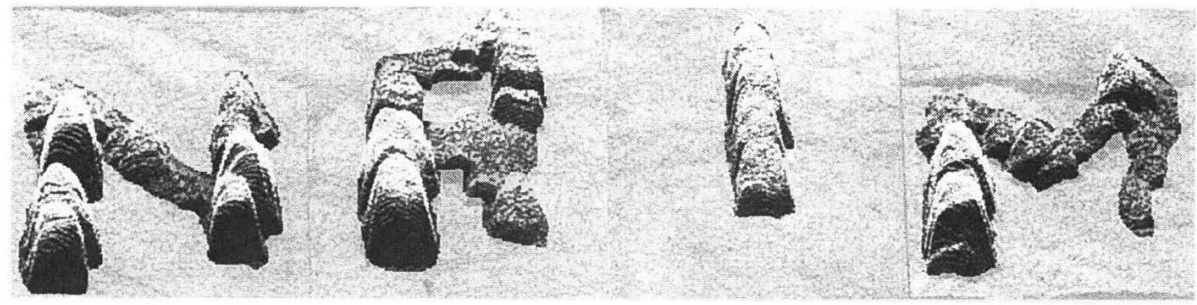

$2 \mu \mathrm{m}$

図 5 金電極上に銅の電解析出粒子で描いた NRIMという文字（Z方向は 5 倍拡大）

功している。また Maminら ${ }^{26)}$ は金の探針を用い, 3.5〜 $4 \mathrm{~V}$ のパルス電压を与えることにより電解 放射の原理で金を基盤上に飛ばし地球の地図など を描くことに成功している。いままでの加工は真 空中や大気中で行われたあのであるが，水溶液中 においては著者 ${ }^{199}$ は $0.1 \mathrm{M}$ 硫酸銅水溶液に小量の 硫酸を加えた溶液中でトンネル電流を増して探針 を基盤電極に近づけていくとトンネル電流に比例 する銅の電解析出反応が探針下に起こることを発 見した。この現象を用いて図 5 に示すような文字 を描くことに成功している。

\section{3 その他の機能}

一般に探針と試料の距離 $S$ とトンネル電流密度 $J$ ，トンネルバイアス $V$ との間には次のような関 係が成立する ${ }^{27)}$ 。

$$
\begin{aligned}
& J=\left(\beta V A \phi^{1 / 2} / 4 \pi S\right) \exp \left(-A \phi^{1 / 2} S\right) \\
& \beta=e^{2} / h, \quad A=(4 \pi h)(2 m)^{1 / 2} \quad \cdots \cdots(1)
\end{aligned}
$$

ここで, $\phi$ は仕事関数, $\mathrm{e}$ は電子の電荷, $m$ は電子の質量, $h$ はプランク定数である。式 (1) で示されるようにトンネル電流の試料と探針の距 離に対する変化量は仕事関数に依存する。そこで 探針の距離を変化させたときのトンネル電流の変 化をとりながら走查を行うことで組成の違いを表 すことが可能である。この原理を用いて Hosaka ${ }^{28)}$ らはAsイオンをドープした試料の観察を行い, ドープされた場所を示すことに成功している。こ の手法は走査トンネル分光法 (STS : Scanning Tunneling Spectroscopy)と呼ばれている。AFM を用いたすのでは探針に働く力として, 静電気力, 磁気力, 摩擦力などがあるので, 斥力場での測定, 引力場での測定を同時に行うことによる静電気力

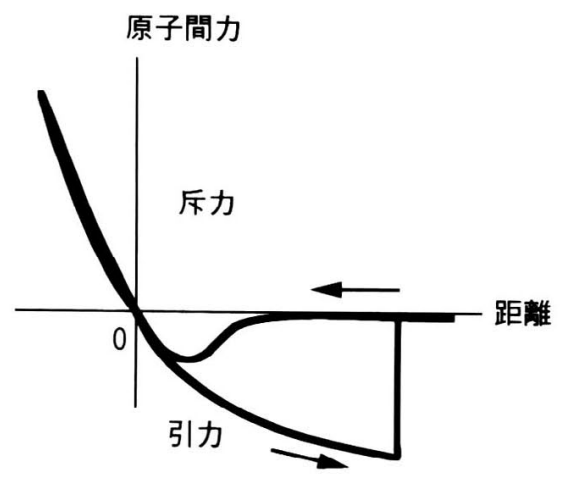

図 6 探針に㗢く力と距離

の測定 ${ }^{29)}$ や，横方向のたわみ測定による摩擦力の 測定 ${ }^{30)}$ な゙目的に応じて種々の力の分布の測定が なされている。また最近 2 種類以上の情報を同時 計測し，新しい情報を得る試みが多くなされてい る。例えば AFMにおいては導電性の探針を用い て表面の凹凸と導電性の同時計測により表面の皮 膜特性の状態を調べることなどがなされている。 このような複数情報の同時測定は今後益々盛んに なると思える。

最後に計測上の問題点であるが, 原子 1 個 1 個 の操作を妨げる最大の要因はドリフトである。現 在の技術ではドリフトを原子操作に影響を与えな い程度に小さくすることは困難で, 今後の最大課 題として残っている。また大気中でフォースカー ブをとると図 6 に示すように探針が一旦斥力モー ドになると表面の吸着層の影響で強い吸着力を受 け探針が離れなくなる現象が起こる。この現象に より特に柔らかいものを走查する場合, 傷をつけ るなどの問題が生じる。この現象を防ぐために探 
針を測定するたびごとに離すというタッピングモー ドの測定が採用されるようになってきている。そ の他にも探針の形状による測定誤差, $100 \mathrm{~nm}$ 程度 の走查範囲におけるピエゾスキャナーの非線形性 の補正など，末解決の問題も多い。

(1994-6-15 受理)

\section{文献}

1) G. Binnig, H. Rohrer, Ch. Gerber and E. Weibel ; Phys. Rev. Lett., 50, 120 (1983)

2) G. Cox, D. Szynka, U. Poppe, K.H. Graf and K. Urban ; Phys. Rev. Lett., 64, 2402 (1990)

3) R. J. Hamers, R. M. Tromp and J. E. Demuth ; Surface Sci., 181, 346 (1987)

4) Ph. Avouris and R. Wolkow ; Phys. Rev. $B$, 39, 5091 (1989)

5) P. Bedrossian, D. M. Chen, K. Mortensen and J. A. Golovchenko ; Nature, 342, 258 (1989)

6) U. K. Kohler, J. E. Demuth and R. J. Hamers ; Phys. Rev. Lett., 60, 2499 (1988)

7 ) J. A. Stroscio and R. M. Feenstra ; J. Vac. Sci. Technol., A, 6, 577 (1988)

8 ) Y. Kuk, P.J. Silverman and N. Q. Nguyen; J. Vac. Sci. Technol., A, 6, 524 (1988)

9 ) A. Brodde, St. Tosch and H. Neddermeyer; J. Microscopy, 152, 441 (1988)

10) J. Wintterlin, J. Wiechers, H. Brune, T. Gritsch, H. Hofer and R. J. Behm ; Phys. Rev. Lett., 62, 59 (1989)

11) F. Jensen, F. Besenbacher, E. Laesgaad and I. Stensgaad ; Phys. Rev., B, 41, 1023 (1990)

12) O. M. Magnussen, J. Hotlos, R. J. Nichols, D. M. Kolb and R. J. Behm; Phys. Rev. Lett., 64, 2929 (1990)

13) T. Hachiya, K. Itaya ; Ultramicroscopy,
42-44, 445 (1992)

14) T. R. Albrecht and C. F. Quate ; J. Vac. Sci. Technol., A, 6, 271 (1988)

15) S. Manne, P. K. Hansma, J. Massie, V. B. Elings and A. A. Gewirth ; Science, 251, 183 (1991)

16) S. Manne, J. Massie, V. B. Elings, P. K. Hansma and A. A. Gewirth ; J. Vac. Sci. Technol., B, 9, 950 (1991)

17）升田博之, 松岡三郎, 長島伸夫 ; 材料之環境, 40, 754 (1991)

18）升田博之, 長島伸夫, 松岡三郎; 機械学会論文集 A編，57，328 (1991)

19）升田博之, 長島伸夫, 松岡三郎 ; 材料之環境, 42, 754 (1993)

20) P. E. Hillner, S. Manne, A. J. Gratz and P. K. Hansma ; Ultramicroscopy, 42-44, 1387 (1992)

21) D. M. Eigler and E. K. Schweizer ; Nature, 344, 524 (1990)

22) P. Zeppenfeld, C. P. Lutz and D. M. Eigler ; Ultramicroscopy, 42-44, 128 (1992)

23）細木茂行, 他; 日本学術振興協会第 151 委員会資料, p.15 (1991)

24) T. R. Albrecht, M. M. Dovek, M. D. Kirk, C. A. Lang, C. F. Quate and D. P. E. Smith ; Appl. Phys. lett., 55, 1727 (1989)

25）岩柣正志; 金属, 1991年 5 月号, p.43

26) H. J. Mamin, S. Chiang, H. Birk, P. H. Guethner and D. Rugar ; J. Vac. Sci. Technol., B, 9, 1398 (1991)

27) J. Simmons ; J. Appl. Phys., 34, 1793 (1963) 28) S. Hosaka, K. Sagara, T. Hasegawa, K. Tanaka and S. Hosoki ; J. Vac. Sci. Technol., A, 8, 270 (1990)

29) C. M. Mate, G. M. McClelland, R. Erlandsson and S. Chiang; Phys. Rev. Lett., 59, 1942 (1987)

30) R. C. Barrett and C. F. Quate; J. Vac. Sci. Technol., A, 8, 400 (1990) 